\title{
Operation of HCMC-Based Modern Retail Channels
}

\author{
LêE TẤN BỬU \\ Doctor of Philosophy, University of Economics HCMC \\ Email: buult@ueh.edu.vn \\ BÙI THANH TRÁNG \\ Doctor of Philosophy, University of Economics HCMC \\ Email: trangbui@ueh.edu.vn
}

\begin{abstract}
In past years, even though the world and local economies have encountered numerous difficulties, the gross retail revenue of Vietnam has been retained at a high level, reaching the annual average growth rate of $28 \%$. Yet, the retail market of Vietnam in general and that of HCMC in particular is not attractive enough to tempt the world's big retailers into it. This paper looks into the real situation of modern retail channels in HCMC and its ability to attract customers. With the descriptive statistics based on secondary data and a survey of 267 customers, the paper tries to evaluate the customer attraction ability of HCMC-based modern retail channels by examining such factors as product type and quality, the role and status of modern retail channels, display, price, sales promotion campaigns, and service quality of modern retail channels. The paper also recommends several measures to promote modern retail channels.
\end{abstract}

Keywords: retail situation, modern retail channels, HCMC supermarkets and trade centers 


\section{AN OVERVIEW OF VIETNAM'S RETAIL MARKET}

In 2011, the gross domestic retail revenue reached VND2,000 trillion, equaling US\$86bn and constituting 15 to 16 percent of the GDP. With a population of around 87 million, the demand for consumer goods is expected to rise in upcoming years and to be a happy hunting ground for retailers. Given commitments to open the retail market when joining WTO, Vietnam has officially allowed foreign investors to take part in the market; yet the number of big retailers in the world are only a handful. Although the Global Retail Development Index (GRDI) of Vietnam has constantly dropped in past years, Vietnam is ranked ninth out of ten countries with the highest level of market attractiveness and retail development in the period 2002-2011. As forecast by AT Kearney, Vietnam's retail market is quite tempting because of its big market size and numerous consumers; and modern retail channels are an indispensable development trend in the future. In the context of economic recession and the fierce competition among local and foreign enterprises, it is necessary to look into the retail development in past years to make improvements to retail and sustain the modern retail channels. Therefore, this paper aims to analyze the retail trade in Vietnam and HCMC in past years and determinants of customers' gravitation towards modern retail channels and then offers several recommendations to develop modern retail channels in the context of world economic integration.

\section{METHODOLOGY}

The paper analyzes retail statistics in Vietnam and HCMC within the period 2007 - 2011 to shed light on reasons for the downturn in the retail trade and its incapability to attract world's big retailers. The research subjects are 267 customers in HCMC who regularly do shopping at Co.opmart, BigC, Vinatex, Maximark, Lotte Mart, Diamond Plaza, Parkson, and Vincom. Regarding their gender, females constitute $80 \%$ and males $20 \%$. In fact, the percentage of female customers, as observed, quadruples that of males. Majority of respondents are patrons of chosen trade centers and supermarkets. Regarding the frequency of shopping at trade centers and supermarkets, around $20 \%$ of respondents do twice a week and around $35 \%$ doing at least once a week. The paper concentrates on analyzing the attractiveness of modern retail channels in HCMC based on such factors as product 
types and quality, price, location, display, sale promotion, and staff attitudes. Table 1 indicates that the research samples are highly representative.

Table 1: Characteristics of Samples

\begin{tabular}{llcc}
\hline & & Frequency & As \% \\
\hline \multirow{3}{*}{ Gender } & Female & 213 & 79.8 \\
& Male & 54 & 20.2 \\
& Total & 267 & 100.0 \\
\hline \multirow{3}{*}{$\begin{array}{l}\text { Frequency } \\
\text { shopping }\end{array}$} & Twice a week & 58 & 21.6 \\
& Once a week & 95 & 35.6 \\
& Once every two weeks & 60 & 22.3 \\
& Once every three weeks & 40 & 15.0 \\
& Once a month & 15 & 5.5 \\
& Total & 267 & 100.0 \\
\hline
\end{tabular}

Source: Authors' survey

\section{RETAIL TRADE IN VIETNAM AND HCMC}

\section{a. Retail Trade in Vietnam:}

In past years, difficulties of the world economy have adversely impinged on Vietnam's economy. The high inflation rate, macroeconomic volatility, high bank rate, constant fluctuations in the VND exchange rate to the USD and the gold price, depressing stock market, stock devaluation, shortage of capital, stagnated production, high unemployment rate, and the like have squarely impinged on the purchasing power and the retail market in Vietnam in general and in HCMC in particular. Until late 2011, the gross retail revenue of products and services in Vietnam reached VND2,004 trillion, equaling US\$95bn, a 24.2\% rise compared to the previous year, which may be a $4.7 \%$ rise if the price factor was excluded. Of this retail revenue, the trading sector earned VND1,578.2 trillion, accounting for $78.8 \%$ and a $24.1 \%$ rise compared to the previous year; the hospitality industry 
earned VND227 trillion, accounting for $11.3 \%$ and a $27.4 \%$ rise over the previous year; services earned VND181 trillion, accounting for $9.0 \%$ and making a rise of $22.1 \%$; and tourism earned VND18.2 trillion, accounting for $0.9 \%$ and a rise of $12.2 \%$. The public sector earned VND219.2 trillion, making up $10.9 \%$ and rising by $29.4 \%$ compared with the previous year. Non-public sectors earned VND1,728.1 trillion, equaling $86.3 \%$ and increasing by $23.5 \%$. Foreign-run businesses earned VND57 trillion, equaling $2.8 \%$ and rising by $18.4 \%$ (GSO, 2011).

In the period 2007 - 2011, the compound annual growth rate (CAGR) of the total retail of goods and services reached $28 \%$, which was supposed to be due to the stable economic growth pace, the expansion of market share, the population of 87 million, consumers' increased demand (70\% of income is for shopping), and living standards enhanced in every corner of the country.

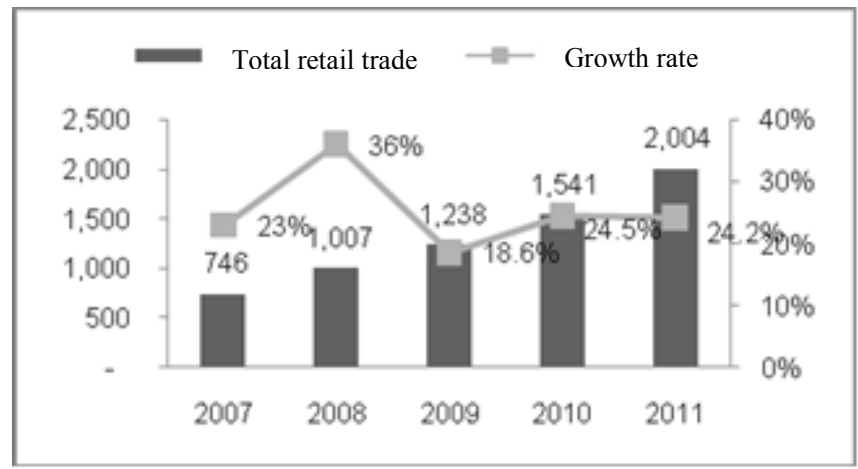

Figure 1: Total Retail of Goods and Services and the Growth Rate of Vietnam Source: GSO

Given commitments to the WTO, Vietnam has opened its retail market since Jan.1, 2009; yet there has been few real investors apart from some 'explorers' who come to identify Vietnam's retail market investment opportunities and devise longterm investment strategies.

To evaluate the attractiveness of retail market, investors often consider the Global Retail Development Index (GRDI) annually published by A.T. Kearney, an American consultancy company that studies and ranks 30 newly-emerging economies. The GRDI is analyzed by four variables and on the 25-point scale for 
each. The more points a market has, the more attractive it is. The four variables are: (1) country and business risk with zero denoting the highest attractiveness and 100 the lowest; (2) market attractiveness with zero denoting the lowest attractiveness and 100 the highest; (3) market saturation with zero being the saturation point and 100 as the non-saturation point; and (4) time pressure with zero denoting absence of time pressure and 100 denoting the urgency of market penetration.

In June 2012, A.T. Kearney published its latest GRDI report which says that Vietnam falls off the top-30 list of the world's busiest retail markets from the $23^{\text {rd }}$ position, and this is its fourth fall-off in the row. In 2011, dropping three rungs, Vietnam was relegated to the $23^{\text {rd }}$ position, below Sri Lanka, Morocco, and Kazakhstan, and farther behind China or India in ranking. Its market attractiveness of $8.4 \%$ proved that Vietnam's retail market was not really tempting to investors; and together with the country and business risk (35\%), the market saturation (48.8\%), and time pressure (85.1\%), its GRDI reached 44.3\%. Previously in 2008, thanks to the strong economic growth and policies in favor of foreign investors, Vietnam went up three rungs and surpassed India to become the world's most attractive retail market. A year later, Vietnam's market attractiveness dropped to the sixth place in the rankings and then fell off the GRDI's top-10 list in 2010. Many experts believed that setbacks in infrastructure, high premises rental, and the harsh competition were hampering global retailers. In fact, Vietnam's retail market has been in decline so far due to impacts of macroeconomic crisis on the purchasing power, and the close-down of plenty of local retailers.

According to the A.T. Kearney2012 report, newly-emerging retail markets like Brazil, Russia, China and India are the most tempting to international retailers. Additionally, other newly-emerging nations like Georgia, Oman, Azerbaijan, Botswana and Mongolia, despite being small-sized markets, are especially a happy hunting ground due to the rapid rise of the affluent, and international retailers have been competing against each other to penetrate into these markets. A.T. Kearney also puts that technologies have compelled retailers to alter their business strategy in newly-emerging markets. Customer behavior and expectations have been changing due to economic changes and quick access to disclosures. Consumers are acutely aware of labels, goods, and have a tight connection with the community. E- 
commerce and modern retail trade have gradually surpassed traditional retail channels.

Even though the GRDI of Vietnam has constantly decreased in the past years, Vietnam, in the period 2002-2011, was ranked ninth out of ten countries with the high market attraction and growth pace of retail trade.

Table 2: Ten Countries with High GRDI in 2002-2011 Period

\begin{tabular}{clcccc}
\hline Rank & Country & $\begin{array}{c}\text { Market } \\
\text { Attraction }\end{array}$ & $\begin{array}{c}\text { Development } \\
\text { of Retail }\end{array}$ & $\begin{array}{c}\text { Country and } \\
\text { Business risk }\end{array}$ & Points \\
\hline 1 & China & 37.0 & 14.3 & 10.1 & 61.4 \\
2 & UAE & 38.8 & 8.2 & 11.9 & 58.9 \\
3 & Kuwait & 31.4 & 7.2 & 9.9 & 48.6 \\
4 & Russia & 30.4 & 8.1 & 7.8 & 46.4 \\
5 & Saudi Arabia & 25.6 & 7.4 & 10.9 & 43.9 \\
6 & India & 25.8 & 8.0 & 8.2 & 42.0 \\
7 & Brazil & 23.6 & 7.5 & 9.0 & 40.1 \\
8 & Turkey & 21.3 & 7.3 & 8.8 & 37.4 \\
9 & Vietnam & 23.3 & 6.9 & 7.1 & 37.3 \\
10 & Chile & 16.4 & 8.3 & 12.2 & 36.0 \\
\hline
\end{tabular}

Source: AT Kearney (2011), Global Retail Development Index, 10 Year Retrospective

According to AT Kearney (2011), within the past decade, Vietnam was ranked in the top five economies (i.e. China, India, Russia, Vietnam, and Chile) with the per capita retail spending (or the CAGR 2001-2010) being higher than the average of $9 \%$ (the per capita retail spending of Vietnam was $12 \%$ ). Vietnam's average growth rate of modern retail channels was $28 \%$, higher than the world average of $20 \%$. As AT Kearney estimates, Vietnam's retail market is still attractive thanks to its market size and increased number of consumers. It is foreseen that Vietnam's retail market will have attracted US\$113bn, and the population will rise to around 
89 million. If the macroeconomic stability is assured and the market attraction is recovered, Vietnam's retail trade will supposedly soar in upcoming years.

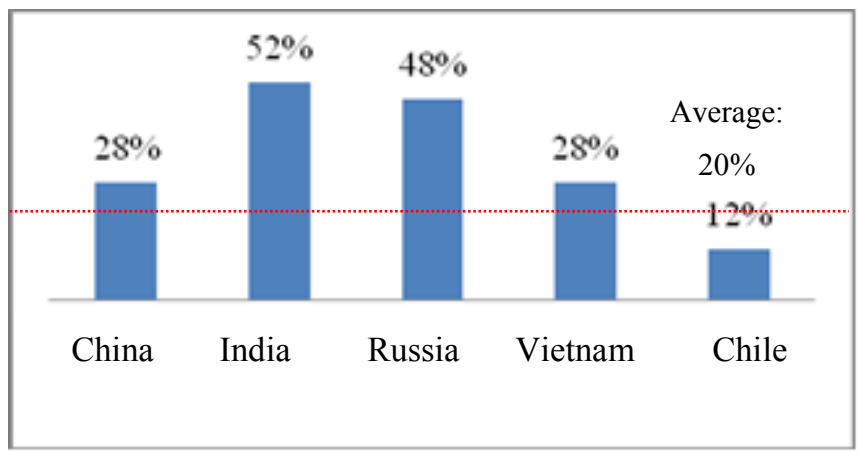

Figure 2: Ranks of Top Five Countries in Terms of the Compound Annual Growth Rate of Modern Retail Channels in the Period 2002-2010

Source: AT Kearney (2011)

\section{b. Retail Trade in HCMC:}

The gross retail revenue of goods and services in HCMC in 2011 reached VND459.5 trillion, rising $23.5 \%$ compared with the preceding year and equaling a quarter of the national total circulation of retail goods. Excluding price fluctuations, the total retail revenue in 2011 increased $7.2 \%$ compared to the $17.8 \%$ of the 2010 . In the period 2007-2011, the CAGR of the total circulation of retail goods and services in $\mathrm{HCMC}$ was $24 \%$.

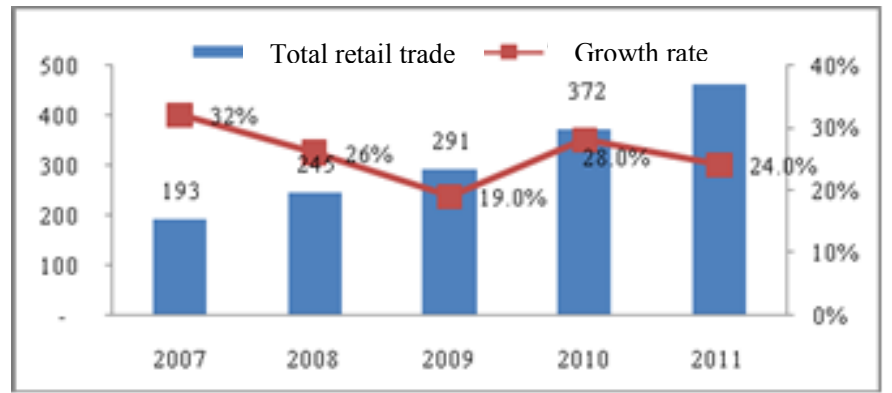

Figure 3: Total Retail Trade of Goods and Services, and the Growth Rate of HCMC

Source: GSO 
Concerning HCMC-based retail channels, until late 2011, there have been 99 supermarkets (i.e. 69 full-line department stores and 30 specialized ones); and 92\% of them are of local enterprises which account for $68 \%$ of total supermarket investments in the locality. The percentage of foreign-run supermarkets is merely $8 \%$, which holds $32 \%$ of total supermarket investments. Up till now, there have been 28 trade centers in HCMC, including big ones like Diamond Plaza, Parkson, Vincom, Now Zone, and Zen Plaza.

In addition to the development of supermarkets and trade centers, the system of convenient stores has been expanded. A convenient store is indeed a small-sized supermarket which trades in basic necessities. Till 2011, there have been over 1,000 convenient stores in HCMC. Specifically, Vissan has established more than 100 convenient stores in the city, and joint stock companies also hold more than 30 ones. Saigon Co.op has developed the system of convenient stores named Co.op Food. Shop \& Go JSC possesses a chain of more than 40 convenient stores named SHOP \& GO in both HCMC and Hà Nội. Moreover, there are also many other convenient stores of G7 Mart, Vmart, Best\&Buy, Speedy, Day \& Night, Family Mart, and so son. However, the operation of convenient stores has been in predicament due to exorbitant premises rental and fierce price competition with family-run grocery stores.

Table 3: Evaluate the Customer Attraction of HCMC-Based Modern Retail Channels

\begin{tabular}{|c|c|c|c|}
\hline $\begin{array}{l}\text { Observed } \\
\text { variables }\end{array}$ & Explanation & Mean & Standard deviation \\
\hline HH1 & Goods are diverse and numerous. & 4.1348 & 0.6579 \\
\hline $\mathrm{HH} 2$ & There are various brand names. & 4.0449 & 0.7136 \\
\hline HH3 & $\begin{array}{l}\text { Goods are always available and there are new } \\
\text { products. }\end{array}$ & 3.9738 & 0.7429 \\
\hline HH4 & Goods are properly labeled and have clear origin. & 3.9363 & 0.7656 \\
\hline HH5 & Goods for sale are of high quality. & 4.0000 & 0.7044 \\
\hline $\mathrm{GC} 1$ & $\begin{array}{l}\text { Prices of products offered in supermarkets match } \\
\text { the quality. }\end{array}$ & 3.8127 & 0.8899 \\
\hline
\end{tabular}


Prices of products offered in trade centers match the quality.

3.7715

0.8865

Prices are clearly quoted and customers are not
worried about buying things at an expensive cost.

Prices are clearly quoted and customers are not
worried about buying things at an expensive cost.

$3.8352 \quad 0.8816$

GC4 Prices listed in supermarkets and trade centers are not much higher than any other retail stores

$3.9738 \quad 0.8107$

\begin{tabular}{|c|c|c|c|}
\hline VT1 & Approachabilitiy & 3.8464 & 0.7626 \\
\hline VT2 & Located near to your house or office. & 3.809 & 0.7786 \\
\hline VT3 & $\begin{array}{l}\text { Supermarkets and trade centers are wide and } \\
\text { comfortable }\end{array}$ & 3.9064 & 0.7625 \\
\hline VT4 & Shopping places are clean and airy & 3.9513 & 0.6838 \\
\hline VT5 & Retail stores are easily accessible. & 3.8951 & 0.6520 \\
\hline TB1 & Goods are displayed in an eye-catching manner. & 3.7566 & 0.9241 \\
\hline TB2 & Easy to seek, see and get goods & 3.633 & 0.9343 \\
\hline TB3 & $\begin{array}{l}\text { Goods are displayed on different shelves with clear } \\
\text { instructions. }\end{array}$ & 3.8614 & 0.9614 \\
\hline TB4 & Convenient to buy and pay. & 3.7978 & 0.9559 \\
\hline NV1 & Sales clerks are willing to serve customers. & 3.7491 & 0.7103 \\
\hline NV2 & $\begin{array}{l}\text { Sales clerks are dedicated to answering customers' } \\
\text { queries. }\end{array}$ & 3.8202 & 0.7290 \\
\hline NV3 & Sales clerks are hospitable and approachable. & 3.6742 & 0.6565 \\
\hline NV4 & Sales clerks are courteous and helpful. & 3.6779 & 0.6612 \\
\hline KM1 & $\begin{array}{l}\text { Supermarkets and trade centers often launch sale } \\
\text { promotions programs. }\end{array}$ & 3.7828 & 0.8915 \\
\hline KM2 & Promotions programs are attractive. & 3.7603 & 0.8814 \\
\hline KM3 & $\begin{array}{l}\text { There are many promotions programs intended for } \\
\text { regular customers. }\end{array}$ & 3.8614 & 0.8712 \\
\hline KM4 & $\begin{array}{l}\text { Supermarkets and trade center often give bonuses } \\
\text { to patrons. }\end{array}$ & 3.9738 & 0.8107 \\
\hline
\end{tabular}

Source: Authors' survey 
According to a survey conducted in HCMC, Hà Nội, Cần Thơ and Đà Nẵng by Kantar Worldpanel, the number of modern retail channels including supermarkets, trade centers and convenient stores has shown an onward trend and constituted $18 \%$ of market shares; whereas traditional retail channels such as traditional markets, family-run groceries, still hold a large share of $82 \%$.

\section{CUSTOMER ATTRACTION ABILITY OF HCMC-BASED MODERN RETAIL CHANNELS}

While traditional retail channels still retain the leading position, modern ones have been developing and gradually fortified their footholds in the HCMC market. Customers become fond of shopping at supermarkets and trade centers due to their tidiness, convenience, good-quality products, eye-catching display, hospitable sales clerks, and plenteous promotion programs. In order to evaluate the attractiveness of HCMC-based modern retail channels, the paper studies variables including product type and quality, price, location, display, promotion, and sales clerks' attitude (Table $3)$.

As the results indicate, the factor "product type and quality" bears the highest value of 4.0, which shows that customers find products of supermarkets, and trade centers are abundant and have diverse types, clear origin as well as good quality. In other words, modern retail channels have become appealing to shoppers.

The impact of "location of modern retail channels" is medium with the value of 3.9. A retail store with a convenient and approachable location and a comfortable atmosphere will attract more shoppers. The factor "price" having the value of 3.8 implies that shoppers find product prices listed in supermarkets and trade centers match the quality and are not much higher that those in traditional retail channels. Majority of shoppers have a sense that prices are clearly quoted in supermarkets and trade centers and they are not worried about being charged expensively or bargaining.

The "product display", with the value of 3.8, is not at a high level. A supermarket or trade center with eye-catching and approachable display and clear directions will be more appealing to shoppers. Besides, efforts should be made to reduce the time spent at checkouts. 
Regarding to "promotion programs" which has the value of 3.75, promotion programs, as estimated by shoppers, are rather tempting. In order to attract more shoppers, supermarkets and trade centers should regularly conduct promotion and discount programs for the sake of regular shoppers.

Most of modern retail channels heavily attend to establishment of a modern commercial culture; and thus besides stated factors, the sales clerks' attitude is also significant. This attitudinal factor, which bears the value of 3.6, reflects a low service quality. Accordingly, supermarkets and trade centers should attend to customer care and retain a good relationship with shoppers to enhance the service quality as well as the competitiveness.

\section{RECOMMENDATIONS}

Based on analyses of the situation of modern retail channels in HCMC and its ability to attract customers, the paper offers the following recommendations:

- Opt for a prime location to establish modern retail channels: In the context of expensive premises rental, poor infrastructure planning, decreased purchasing power and high construction cost, it may be a big challenge for retailers to choose an excellent position to develop their retail channels. Thus, it is advised to think twice about issues such as the population density and existing retail modes (i.e. traditional markets, supermarkets, trade centers, etc.); preferentially develop large-sized supermarkets and trade centers in central districts, and medium and small-sized ones on the outskirts of the city. Particularly, the system of convenient stores should be established in remote districts.

- Diversify goods and ensure the quality: Distributors within the modern retail channel system should regularly survey customers' demand in order to choose appropriate goods and services. It is necessary to classify goods with high, medium and low frequency of purchase to facilitate the punctual import schedule and inventory control; liaise with suppliers to acquire diverse and high-quality products at an acceptable cost; dispose of near-to-expire products and leave out expired ones.

- Enhance customer services: Retailers need to develop or adopt a modern mode of customer care. Staff must be highly responsible, hospitable, courteous and dedicated to customers. Sale services must be professional; and each salesperson 
must master related skills and expertise, as well as establish a good relationship with customers. Regular training courses on customer relation maintenance and customer service administration should be held. Additionally, the salesperson's attitude, a good measure of customer service, is also reflected by a shorter time at checkouts and a hospitable atmosphere which will make customers comfortable to do shopping.

- Diversify promotion programs: As results indicate, most customers are interested in promotion programs and anticipate more interesting ones. Promotion programs of supermarkets and trade centers, such as issuance of loyalty cards, gifts, discounts or the like should be regularly held and renovated from time to time. Furthermore, operators of supermarkets and trade centers should request manufacturers and suppliers to jointly undertake promotions at points of sale so as to attract customers, advertise products and create an amusing shopping atmosphere on weekends.

\section{LIMITATIONS AND ORIENTATIONS FOR FURTHER RESEARCH}

Besides practical contributions, there are still some limitations such as the destitution of generalization due to its mere concentration on big supermarkets and trade centers in HCMC and utilization of the convenient sampling method. Moreover, the paper analyzed the retail trade on the basis of secondary data while the primary data are only used for descriptive statistics. Therefore, in order to study impacts of each factor on the customer attraction, further researches should employ more analytical methods such as various linear regressions

\section{References}

A.T. Kearney (2011), Global Retail Development Index (GRDI): A 10-Year Retrospective.

GSO, Statistical Yearbooks 2007, 2008, 2009, 2010, 2011, Thống kê Publisher, Hà Nội.

Hair, J.F., R.E. Anderson, R.L. Tatham, and W.C. Black (1998), Multivariate Data Analysis with Readings, 5th Ed., Prentice-Hall, New Jersey.

Nguyễn Đình Thọ \& Nguyễn Thị Mai Trang (2006), Chất luợng dịch vu siêu thị, Nghiên cứu khoa hoc Marketing, HCM-VNU Publisher.

Nguyễn Đông Phong (2010), Phát triển thuoong mại bán lẻ trên địa bàn TP.HCM để đáp úng yêu cầu hội nhập kinh tế quốc tế, Ministerial research project.

Nguyễn Ngọc Hòa (2006), Xây dựng mô hình chuỗi siêu thị Co.opmart tại VN, unpublished doctoral dissertation. 